\title{
THE EFFICIENCY OF THE RADIOCESIUM BINDERS- AFCF AND CLINOPTILOLITE IN BROILER CHICKENS EXPOSED TO ALIMENTARY CONTAMINATION WITH ${ }^{137} \mathrm{Cs}$
}

\author{
SLAVATA BRANISLAVA and VITOROVIĆ GORDANA \\ Faculty of Veterinary Medicine, Belgrade \\ (Received 19. May 2004)
}

Various radioprotective agents are used with the aim of protecting animal and food of animal origin from radioactive contamination. The most efficient radiocaesium binder in animals is ammonium ferric hexacyanoferrate (AFCF). Based on the results obtained so far it can be concluded that the protection efficiency of AFCF in broiler meat and liver was $88 \%$, after a single ${ }^{137}$ Cs contamination, followed by immediate AFCF administration via gastric tube, while when mixed in the feed pellets this rate increased to $95 \%$. In broiler chickens given clinoptilolite via gastric tube, the protection efficiency for meat and liver was $50 \%$, while clinoptilolite mixed in the feed pellets showed the lowest protection efficiency in meat and liver of only $28 \%$. chickens, ${ }^{137} \mathrm{Cs}$

Key words: radiocaesium binders, AFCF, clinoptilolite, broiler

\section{INTRODUCTION}

Higher levels of radioactivity and the unequal distribution of radioactive substances in the environment have led numerous researchers to seek adequate means to protect animals and food of animal origin from radioactive contamination. From the aspect of veterinary medicine, the highest importance is attached to the management of protection of domestic animals and their products in times of increased environmental radiocontamination. The main use of radiocaesium binders is to allow unrestricted human consumption of food of animal origin.

In the case of internal contamination with ${ }^{137} \mathrm{Cs}$, different substances have been used to bind this particular radionuclide in the animal digestive tract, thus preventing its absorption and distribution in tissues and organs (Mladenović et al., 1997). Early studies showed that high levels of potassium in the food stimulate caesium excretion out of the animal organism (Mraz, 1959; Crage, 1961). Nigrović (1965) and Gligorijević (1970) used Berlin blue as a radiocaesium binder, but its protection efficiency was only $23.0 \%$. A common radiocaesium binder in use is bentonite with a protection efficiency of 42.0-70.0\% (Mirna, 1970; Hansard, 1964; Hazzard, 1966; 1969a; Hazzard et al., 1969b; Iben et al., 1987; Rachubik 2000b).

Ammonium ferric hexacyanoferrate (AFCF) is considered to be the most efficient radiocaesium binder in animals. After the Chernobyl accident, numerous 
authors investigated radioprotective efficiency of AFCF in various animal species (Margenthal, 1988; Bailer, 1988; Giese, 1989; Vitorović 1992; Vićentijević, 2003). Thus, it was established thata protection effect of $85.0-99.0 \%$ may be achieved by giving AFCF at 0.2- $3.0 \mathrm{~g}$ per animal.

Recent literature data also mention clinoptilolite as a radiocaesium binder showing a protection efficiency of 50.0-70.0\% in broiler chicken meat and edible inner organs (Mladenović et al. 1997; Mladenović 2000; Vitorović et al., 2002; Vićentijević, 2003).

The objective of this investigation was to compare these two caesium binders: AFCF and the mineral clinoptilolite, following a single alimentary contamination of broiler chickens with ${ }^{137} \mathrm{Cs}$.

\section{MATERIAL AND METHODS}

In this experiment 35-day-old broiler chicken of the linear hybrid Hibro were used, with 5 chickens placed in each cage. Food and water intake was ad libitum. Mixed pellets containing $18 \%$ protein were used for feeding.

The experiment encompassed 100 birds randomly divided into five groups, each consisting of 20 broiler chickens (scheme 1). Each group was further split into four subgroups, each comprising 5 chickens sacrificed was on the $2^{\text {nd }}, 4^{\text {th }}$, $8^{\text {th }}$, and $24^{\text {th }}$ hour of the experiment respectively. The chickens were given a single dose of aqueous ${ }^{137} \mathrm{CsCl}$ solution $(3 \mathrm{ml})$, with a specific activity of $750 \mathrm{~Bq} / 3 \mathrm{ml}$. AFCF $(0.2 \mathrm{~g})$ and clinoptilolite $(2 \mathrm{~g})$ application routes were varied. They were administered via gastric tube as an aqueous solution (AFCF) or suspension (clinoptilolite) or mixed in the feed pellets offered ad libitum immediately following the contamination.

The zero group was neither given ${ }^{137} \mathrm{CsCl}$ solution nor radiocaesium binders. Food and water intake was ad libitum.

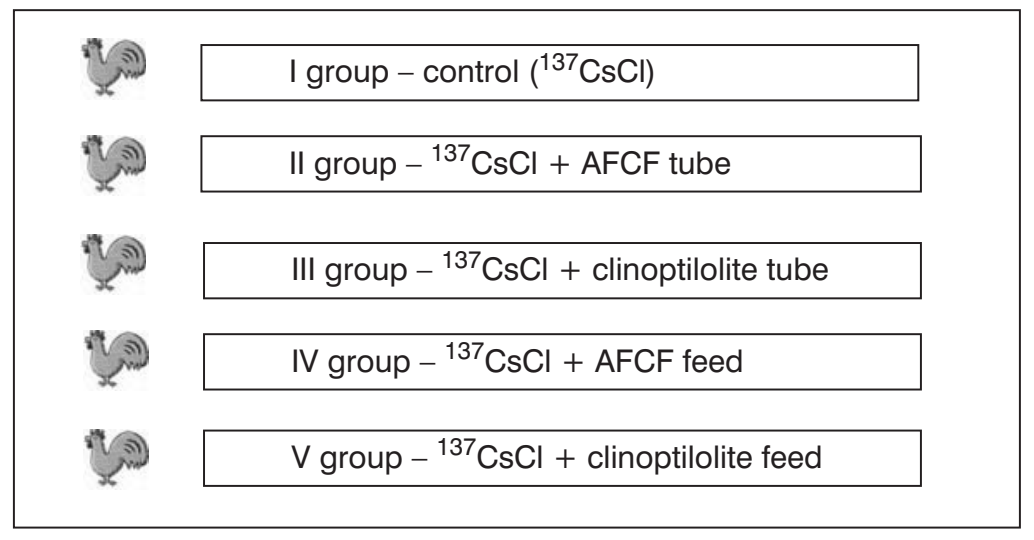

Figure 1. Experimental sheme 
Acta Veterinaria (Beograd), Vol. 54, No. 5-6, 437-446, 2004.

${ }^{137} \mathrm{Cs}$ specific activity in light and dark meat, liver and gizzard were determined by a gammaspectrometric method. All samples were chopped and then homogenised. The average weight of white and dark meat samples was 150$250 \mathrm{~g}$, while that of inner organs (liver and gizzard) samples amounted to 30-60 g. The gamma irradiation level was measured by a pure germanium vertical detector (HPGe- high purity germanium, Ortec). The detector efficiency was 30,3\%, allowing us to detect all the radionuclides of interest above the stated lowest detection point. Measuring time for samples and basic irradiation level was $12000 \mathrm{~s}$.

\section{RESULTS AND DISCUSSION}

Table 1 shows the ${ }^{137} \mathrm{Cs}$ specific activity found in broiler chicken dark meat after a single alimentary contamination and immediate protection with AFCF and clinoptilolite administered via gastric tube or mixed in the feed pellets.

The highest level of ${ }^{137} \mathrm{Cs}$ specific activity was measured in the dark meat of the control group $(39,6-300,0 \mathrm{~Bq} / \mathrm{kg})$, in which the broilres were administered only ${ }^{137} \mathrm{Cs}$, without any countermeasures.

The lowest level of ${ }^{137} \mathrm{Cs}$ specific activity was found in the dark meat of the group 4of broilers $(7,6-14,5 \mathrm{~Bq} / \mathrm{kg})$, which were given AFCF mixed in the pellets. In the group of broilers, where AFCF was administered via gastric tube the ${ }^{137} \mathrm{Cs}$ specific activity ranged between $15,1-38,6 \mathrm{~Bq} / \mathrm{kg}$.

In the broiler chickens given clinoptilolite via gastric tube (group 3), ${ }^{137} \mathrm{Cs}$ specific activity ranged between 11.6 and $243.7 \mathrm{~Bq} / \mathrm{kg}$, while in the group of broiler chickens receiving clinoptilolite mixed in the feed, ${ }^{137} \mathrm{Cs}$ specific activity varied between 22.4 and $210.4 \mathrm{~Bq} / \mathrm{kg}$.

In Table 2 it can be seen that the percentage of ${ }^{137} \mathrm{Cs}$ deposition was lower in dark broiler chicken meat, after AFCF and clinoptilolite administered differently.

The highest protection efficiency of $91.0 \%$ (80-97\%) was observed in the broiler chickens receiving AFCF in the feed, while an increase of protection related to time was also noticeable, which is in accordance with earlier findings by other authors.

In the group 2 broiler chickens, in which AFCF was administered via gastric tube, the protection efficiency amounted to $82.0 \%$ (62-90 \%) compared with the control group. The lowest protection efficiency was found in the chickens sacrificed in the second hour of the experiment (62\%). In the broiler chicken sacrificed in the $4^{\text {th }}, 8^{\text {th }}$, and $24^{\text {th }}$ hour of the experiment, the protection level increased to $89.0 \%$, complies with the findings of other authors (Giese, 1971; Vitorović, 1992).

Clinoptilolite administered via gastric tube had a protection efficiency of $53 \%(18-71 \%)$, with the lowest protection efficiency recorded 24 hours after contamination. Mladenović et al. (1997) determined clinoptilolite protection efficiency in broiler chicken meat to be $68 \%$ in the first three hours, while later on it increased up to $75 \%$. 

and clinoptilolite in broiler chickens exposed to alimentary contamination with ${ }^{137} \mathrm{Cs}$
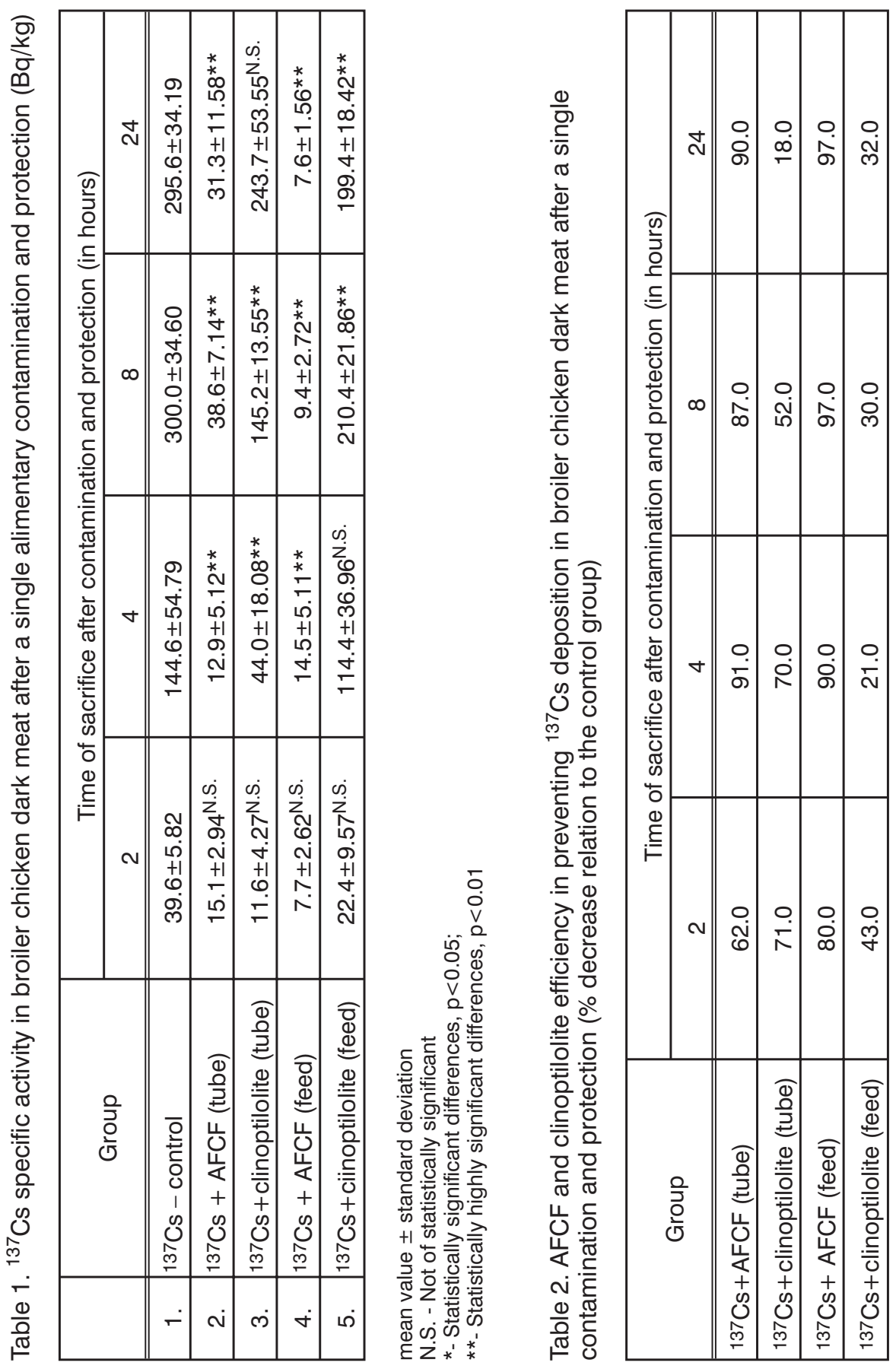
Clinoptilolite mixed in the feed showed a protection efficiency of $31.0 \%$, the highest level of protection being in the chickens sacrificed two hours after contamination.

The ${ }^{137} \mathrm{Cs}$ specific activity found in broiler chicken white meat after a single alimentary contamination and immediate protection with AFCF or clinoptilolite administered via gastric tube or mixed in the feed are shown in Table 3.

The highest ${ }^{137} \mathrm{Cs}$ specific activity was measured in white meat of the control group $(44.7-1176 \mathrm{~Bq} / \mathrm{kg})$, which received only ${ }^{137} \mathrm{Cs}$, and no radiocaesium binders.

The lowest ${ }^{137} \mathrm{Cs}$ specific activity in white meat was measured in the group of chicken, where AFCF was mixed in the feed $(2.9-4.7 \mathrm{~Bq} / \mathrm{kg})$. In the group of broilers, receiving AFCF via gastric tube ${ }^{137} \mathrm{Cs}$ specific activity ranged from 5.2 to $16.8 \mathrm{~Bq} / \mathrm{kg}$.

In the white meat of broiler chickens, to which clinoptilolite was administered via gastric tube ${ }^{137} \mathrm{Cs}$ specific activity varied from 3.2 to $89.1 \mathrm{~Bq} / \mathrm{kg}$, while in the fifth group of broilers, where clinoptilolite was mixed in the feed ${ }^{137} \mathrm{Cs}$ specific activity ranged from $19.2-68.6 \mathrm{~Bq} / \mathrm{kg}$.

The relative decrease of ${ }^{137} \mathrm{Cs}$ deposition decrease in broiler chicken white meat, after radioprotection by AFCF and clinoptilolite, using two different modes of application are shown in Table 4.

Broiler chickens fed AFCF in the feed exhibited the highest protection effect amounting to $94 \%$ on average, with a tendency to increase with time.

Protection efficiency of a somewhat lower degree was observed in broiler chickens given AFCF via gastric tube, with an average value of $87.0 \%$, which confirms results of other authors (Giese, 1971, 1988, 1989; Bailer, 1988; Vitorović, 1992).

The average via-gastric-tube-administered clinoptilolite protection efficiency was $59.0 \%$. The highest efficiency occurred in the second hour and the lowest after 24 hours. The results obtained are similar to those for the dark meat, so they are comparable to those found by Mladenović et al. (1997).

Clinoptilolite mixed in the feed gave the lowest protection efficiency, the average value being $35.0 \%$.

The results for ${ }^{137} \mathrm{Cs}$ specific activity found in the broiler chicken liver, after a single alimentary contamination and protection with AFCF and clinoptilolite administered via gastric tube or mixed in the feed are given in Table 5.

The highest ${ }^{137} \mathrm{Cs}$ specific activity was measured in the liver of control group chickens $(315.7-638.4 \mathrm{~Bq} / \mathrm{kg})$, receiving only ${ }^{137} \mathrm{Cs}$, and no caesium binders.

The lowest ${ }^{137} \mathrm{Cs}$ specific activity was found in the liver of the group of chickens, where AFCF was mixed in the feed $(7.6-28.5 \mathrm{~Bq} / \mathrm{kg})$.

In liver samples, from the group receiving AFCF via gastric tube, ${ }^{137} \mathrm{Cs}$ specific activity ranged between 50.2 and $62.0 \mathrm{~Bq} / \mathrm{kg}$. In broiler chickens given clinoptilolite via gastric tube, ${ }^{137} \mathrm{Cs}$ specific activity ranged between 47.5 and $360.1 \mathrm{~Bq} / \mathrm{kg}$, and in those receiving clinoptilolite mixed in the feed, it was 203.0 628.0 Bq/kg.

The percentage decrease of ${ }^{137} \mathrm{Cs}$ in broiler chicken liver, after AFCF and clioptilolite administration in different ways is given in Table 6. 

and clinoptilolite in broiler chickens exposed to alimentary contamination with ${ }^{137} \mathrm{Cs}$
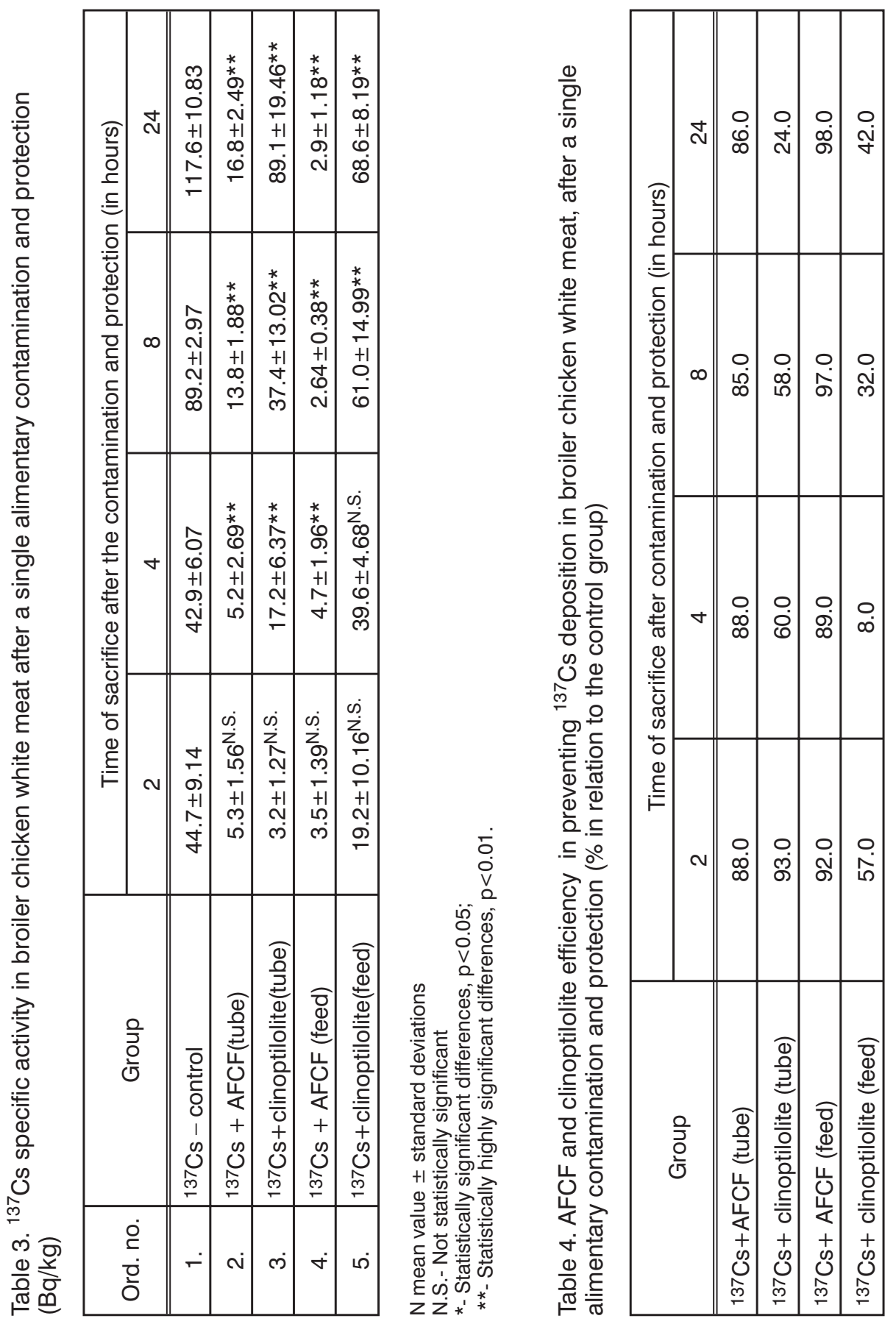
Acta Veterinaria (Beograd), Vol. 54, No. 5-6, 437-446, 2004.

Slavata Branislava et al. The efficiency of the radiocesium binders - AFCF

and clinoptilolite in broiler chickens exposed to alimentary contamination with ${ }^{137} \mathrm{Cs}$
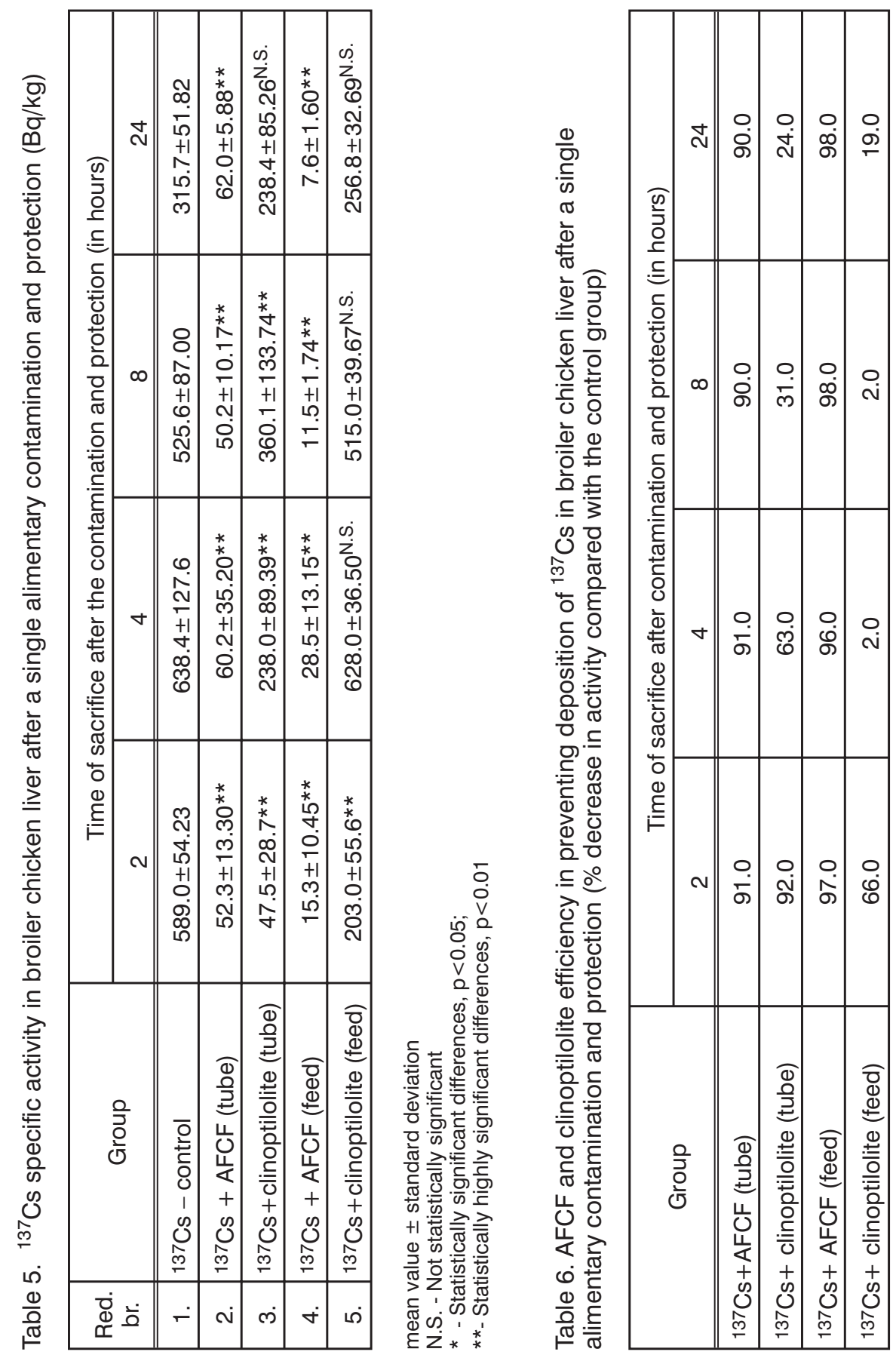
The highest protection efficiency occurred in the broiler chickens given AFCF mixed in the feed, with an average value of $97.0 \%$, a somewhat lower value $(90.0 \%)$ was found in those receiving AFCF via gastric tube. The results obtained are in accordance with earlier data (Mergenthal, 1988; Vitorović, 1992;).

Clinoptilolite administered via gastric tube showed a protection efficiency of $52.0 \%$, with a tendency to decrease in with time. Clinoptilolite mixed in the feed showed the lowest protection efficiency $(22.0 \%)$. The highest protection was observed in the broilers sacrificed after 2 hours, which is in accordance with the results of Mladenović (1997).

\section{CONCLUSION}

1. After a single alimentary contamination of broiler chickens with aqueous ${ }^{137} \mathrm{Cs}$ solution and protection by AFCF, the highest level of protection was achieved by using AFCF in water solution or mixed in the feed pellets. The protection effect achieved in meat and liver ranged between $87-97 \%$.

2. The mineral clinoptilolie had lower protection effect as a caesium binder. Simultaneous application of ${ }^{137} \mathrm{Cs}$ solution and an aqueous clinoptilolite suspension gave a protection in meat and liver of $53.0-59.0 \%$.

3. From the radiation and hygienic aspects, the use of AFCF as a component of broiler chicken feed, should decreased transfer coefficient $(T p=1)$ to minimum. Meat and inner edible organs might be consumed with negligible risk of radioactive contamination.

4. The use of clinoptilolite in its natural form as a domestic countermeasure may be advised in exceptional circumstances, it being recommended for daily administration in order to achieve a protection effect of $55.0-70.0 \%$ in broiler chicken meat and edible organs.

Address for correspondence:

Branislava Slavata

Departament of Radiation Hygiene,

Faculty of Veterinary Medicine,

Bul. JNA 18, 11000 Belgrade,

Serbia \& Montenegro,

slavatab@vet.bg.ac.yu

\section{REFERENCES}

1. Bailer B, 1988, Zur beschleungten Ausschleidung von Radiocäsium bei Schafen durch Zufûtterung von Amonium - Eisen - Hexacyanoferrat. Inaugural Disertation Hannover.

2. Crage RG, 1961, Uptake and excretion of Cs-134 and potassium in lactating dairy cows, J Dairy Sci, 44, 254-7.

3. Giese W, 1971, Das verhalten von radiocaesium bei laboratorimus und haustieren sowie möglicheiten zur verwinderung der radioaktiven strahlenbelastung. Habilitationschrift, Tierärztliche Hochshule, Hannover.

4. Giese W, 1988, Ammonium-ferric-cyano-ferrate (II) (AFCF) as an effective antidote against radiocaesium burdens in domestic animals and animal derived foods, $\mathrm{Br}$ Vet $\mathrm{J}, 144$, 363-9. 
Acta Veterinaria (Beograd), Vol. 54, No. 5-6, 437-446, 2004

5. Giese W, 1989, Countermeasures for reducing radiocesium in animal derived food, The Sci Total Envir, 85, 317-26.

6. Gligorijević J, Draganović B, Begović J, Gačević M, 1970a, Ispitivanje protekcionog efekta berlinskog plavog kod peroralno kontaminiranih kokoši radiocezijumom-137, V Jugoslovenski simpozijum o rad zaštiti, Zbornik radova, Bled, 58.

7. Hansard SL, 1964, Effects of hydrobiotites upon Sr-89 and Cs-137 retention by ruminant animals, Proc Soc Exp Med, 115, 346-50.

8. Hazzard DG, 1966, In vivo binding of Sr-85 Cs-134 with vermiculite, J Dairy Sci, $49,743$.

9. Hazzard DG, 1969a, Percent Cs-137 and Sr-85 in milk, urine and feces of goats on normal and verxite containing diets, J Dairy Sci, 52, 990-4.

10. Hazzard DG, Withrow TJ, Bruckner BH, 1969b, Verxite flakes for in vivo binding of Cs-134 in cows, $J$ Dairy Sci, 52, 995-7.

11. Iben C, Holdt C, Leibetseder J, 1987, Versuch zur reduction der Cs-137 und Cs-134 rûckstände beim schwein durch beifûtterung adsorbierendr mineralien, In 41 Tagung der Gesellschaft fûr Ernährungsphysiologie der Haustiere, Göttingen.

12. Margenthal A, 1988, Fûtterungsversuch zur erprobung von amonium - eisen - hexacyanoferrat fûr die dekorporation von radiocäsium bei moorschnucken, Inaugural Dissertation - Hannover.

13. Mirna A, 1970, Beinflussing der radioaktiven kontamination von tieren durch zufûterung von tonminaralien, Z Tierphysol, 26, 72-82.

14. Mladenović V, Vitorović G, Vukićević O, 1997, Radioprotekcioni efekat prirodnog zeolita. XIX Jug Simp za zašt od zračenja, Zbornik radova, Golubac, 295-8.

15. Mladenović V, Vitorović G, Slavata B, Vitorović D, Ivković S, Vuković $D, 2000$, In vitro ${ }^{137}$ Cs sorption by natural and monoionic forms of clinoptilolite. Acta Veterinaria, 50, 163-8.

16. Mraz FR, 1959, Influence of dietary potassium and sodium on Cs-134 and K-42 excretion in sheep. $J$ Nut, 68, 655-62.

17. Nigrović V, 1965, Retention of radiocesium by the rats as influenced by Prussian blue and other compounds, Phys Med Biol, 10, 81-91.

18. Rachubik J, Dzuira A, and Kowalski B, 2000b, Bentonite from Polish geological deposits as a countermeasure for reducing the radiocaesium transfer to muscles and inner edible organs of broiler chickens. Mineralstoffe, Mengen-, Spuren- und Ultraspurenelemente idn der Prävention, Jena, 1. und 2. Dezember , 361-6.

19. Vićentijević $M, 2003$, Uporedna ispitivanja protekcione sposobnosti amonijum-gvožđe (III) heksacijanoferata (II) i klinoptilolita kod fazana izloženih alimentarnoj radiokontaminaciji. Magistarska teza, Fakultet veterinarske Medicine, Beograd.

20. Vitorović Mićić G, 1992, Primena amonijum-gvožđe (III) heksacijanoferata (II) u zaštiti pilećeg mesa od kontaminacije radiocezijumom. Doktorska disertacija Fakultet Veterinarske Medicine, Beograd.

21. Vitorović G, Slavata B, Stošić K, Mladenović V, Vitorović D, 2002, The effect ${ }^{137}$ Cs binding in broiler chickens Agr and Food Sci Finland, 11,137-41. 


\title{
EFIKASNOST SUPSTSTANCI KOJE VEZUJU RADIOAKTIVNI CEZIJUM - AFCF I KLONOPTILOLITA KOD BROJLERA IZLOŽENIH ALIMENTARNOJ KONTAMINACIJI SA ${ }^{137} \mathrm{CS}$
}

\author{
SLAVATA BRANISLAVA i VITOROVIĆ GORDANA
}

\section{SADRŽAJ}

U cilju zaštite životinja i namirnica animalnog porekla od radioaktivne kontaminacije koriste se različita radioprotekciona sredstva. Kao najefikasniji radioprotektor kod životinja se pokazao amonijum-gvožđe (III) heksacijanoferat (II) ili AFCF. Na osnovu dobijenih rezultata se uočava da je u mesu i jetri brojlera posle jednokratne kontaminacije ${ }^{137} \mathrm{Cs}$ i istovremenog davanja AFCF putem sonde efikasnost zaštite iznosila 88,0\%, dok je AFCF umešan u hranu pokazao veću efikasnost zaštite od 95,0 \%. Kod brojlera koji su dobijali klinoptilolit putem sonde efikasnost zaštite je bila preko 50,0 \% u mesu i jetri, dok je klinoptilolit umešan u hranu pokazao najmanju efikasnost zaštite koja je iznosila 28,0 \% u mesu i jetri brojlera. 